\title{
Neurotrophin-3 Sorts to the Constitutive Secretory Pathway of Hippocampal Neurons and Is Diverted to the Regulated Secretory Pathway by Coexpression with Brain-Derived Neurotrophic Factor
}

\author{
Hooman F. Farhadi, ${ }^{1}$ S. Javad Mowla, ${ }^{1}$ Kevin Petrecca, ${ }^{2}$ Stephen J. Morris, ${ }^{1}$ Nabil G. Seidah, ${ }^{3}$ and \\ Richard A. Murphy ${ }^{1}$ \\ ${ }^{1}$ Center for Neuronal Survival, Department of Neurology and Neurosurgery, Montreal Neurological Institute, McGill \\ University, Montreal, Quebec, Canada H3A 2B4, 2Department of Physiology, McGill University, Montreal, Quebec, \\ Canada H3G 1Y6, and ${ }^{2}$ Laboratory of Biochemical Neuroendocrinology, Clinical Research Institute of Montreal, Montreal, \\ Quebec, Canada H2W $1 R 7$
}

\begin{abstract}
Hippocampal neurons release nerve growth factor (NGF) through the constitutive secretory pathway, thus allowing the protein to be continuously available for promoting nerve cell survival. In contrast, hippocampal neurons use the regulated secretory pathway to process brain-derived neurotrophic factor (BDNF), which alters synaptic activity when released acutely from dense-core vesicles. Thus, understanding how neurons sort and deliver neurotrophins may provide clues to their functions in brain. In this study, we monitored the processing and delivery of neurotrophin-3 (NT-3). Pulse-chase studies, immunocytochemistry, and secretagogue-induced release experiments were performed on cultured hippocampal neurons and AtT-20 cells infected with vaccinia viruses encoding the NT-3 precursor (pro-NT-3). Results show that most newly synthesized NT-3 is released through the constitutive secretory pathway as a result of furin-mediated endoproteolytic cleavage of
\end{abstract}

Neurotrophins are synthesized as high molecular weight precursors containing a prodomain linked to the amino terminus of the mature protein. The two components are separated by endoproteolytic cleavage within either the constitutive or regulated secretory pathways. Understanding how neurotrophins are processed in these pathways may help explain their physiological functions.

Hippocampal neurons and AtT-20 cells in culture process nerve growth factor (NGF) within the constitutive secretory pathway (Mowla et al., 1999). The NGF precursor is cleaved within the trans-Golgi network (TGN) by the endoprotease furin, a member of the subtilisin/kexin-like family of proteases (for review see Seidah et al., 1998; Zhou et al., 1999). Constitutive release of NGF occurs soon after the molecule is synthesized. Thus, as a result of being processed in the constitutive pathway, NGF is continuously available to cells that require it, which is consistent with hippocampal neurons producing NGF as an

\footnotetext{
Received Dec. 23, 1999; revised March 8, 2000; accepted March 17, 2000.

This work was supported by grants from the Medical Research Council of Canada (MRC) to R.A.M. and N.G.S., and by funding from the National Centers of Excellence Program in Neuroscience to R.A.M. and N.G.S. H.F.F. is supported by an MRC Doctoral Research Award, and S.J.M. is supported by a studentship from the Iranian Ministry of Culture and Higher Education. We thank Amgen for providing the antibody to brain-derived neurotrophic factor.

H.F.F. and S.J.M. contributed equally to this work.

Correspondence should be addressed to Dr. Richard A. Murphy, Director, Montreal Neurological Institute, McGill University, 3801 University Street, Montreal, Quebec, Canada H3A 2B4. E-mail: director@mni.lan.mcgill.ca.

Copyright (C) 2000 Society for Neuroscience 0270-6474/00/204059-10\$15.00/0
}

pro-NT-3 in the trans-Golgi network. Pro-NT-3 can also be diverted into the regulated secretory pathway when cells are treated with $\alpha 1$-PDX, a selective inhibitor of furin-like enzymes, or when pro-NT-3 expression is increased by transient transfection methods. In cells coinfected with viruses coding for pro-NT-3 and pro-BDNF, NT-3 is sorted into the regulated pathway, stored in secretory granules, and released in response to extracellular cues together with BDNF, apparently as a result of heterodimerization, as suggested by coimmunoprecipitation data. Taken together, these data show that sorting of the NT-3 precursor can occur in both the constitutive and regulated secretory pathways, which is consistent with NT-3 having both survival-promoting and synapse-altering functions.

Key words: neurotrophin; NT-3; BDNF; constitutive pathway; regulated secretory pathway; heterodimer apoptosis-inhibiting survival factor for basal forebrain cholinergic neurons (for review, see Yuen et al., 1996).

In contrast, hippocampal neurons process brain-derived neurotrophic factor (BDNF) within the regulated secretory pathway (Goodman et al., 1996; Mowla et al., 1999). Intact pro-BDNF is shunted from the TGN into immature secretory granules where it is likely cleaved by prohormone convertase 1 (PC1), another member of the subtilisin/kexin-like endoprotease family (Seidah et al., 1996b; Mowla et al., 1999). BDNF is stored within densecore vesicles (Fawcett et al., 1997; Michael et al., 1997) (for review, see Altar and DiStefano, 1998), and once released, presumably in response to extracellular cues, it can induce changes in neuronal structure (Ventimiglia et al., 1995; Fawcett et al., 2000), membrane depolarization (Kafitz et al., 1999), and changes in synaptic function (for review, see McAllister et al., 1999). Likewise, neurotrophin-3 (NT-3) may regulate neuronal depolarization (Kafitz et al., 1999) and synaptic plasticity (Kang and Schuman, 1995), but as yet little is known about its intracellular sorting in vivo.

Neurotrophins are normally synthesized as noncovalently linked homodimers consisting of two identical chains. When different neurotrophins are coexpressed within the same cell, however, they also form heterodimers. Heterodimers of BDNF and NT-3 are stable, whereas heterodimers involving NGF are not (Radziejewski and Robinson, 1993; Arakawa et al., 1994; Jungbluth et al., 1994; Heymach and Shooter, 1995; Robinson et 
al., 1995). BDNF/NT-3 heterodimers can induce autophosphorylation of Trk receptors, promote the survival of sympathetic neurons in vitro, and induce dopamine uptake in cultures of substantia nigra neurons (Arakawa et al., 1994; Philo et al., 1994). However, the physiological functions of heterodimers remain unknown.

In this study, we monitored the sorting of NT-3 by infecting hippocampal neurons and AtT-20 cells with vaccinia viruses (VVs) encoding pro-NT-3. Pulse-chase studies and immunocytochemistry show that processed NT-3 is primarily released through the constitutive secretory pathway. Inhibition of furinmediated cleavage or overexpression of pro-NT-3 shifts pro-NT-3 sorting into the regulated secretory pathway. NT-3 is also sorted to the regulated secretory pathway when it is coexpressed with BDNF. Immunoprecipitation data suggest that the transfer of NT-3 to the regulated pathway occurs as a result of NT-3 and BDNF heterodimerizing. Thus, either secretory pathway can sort NT-3.

Some of these results have been published previously in abstract form (Farhadi et al., 1998).

\section{MATERIALS AND METHODS}

Cell cultures. Hippocampal neurons were prepared according to the method of Banker and Cowan (1977) as modified by Brewer et al. (1993). Briefly, the hippocampus was dissected from embryonic day 18 (E18) mice (Charles River, Montreal, Quebec, Canada), exposed to trypsin, dissociated mechanically, and grown in $60 \mathrm{~mm}$ collagen/poly-L-lysinecoated dishes. Cells from two litters of mice were plated into six dishes. Cultures were maintained in serum-free Neurobasal medium (Life Technologies, Gaithersburg, MD) containing $0.5 \mathrm{~mm}$ glutamine and $1 \times$ B27 supplement (Life Technologies). AtT-20 cells and COS-1 cells were cultured as reported previously (Seidah et al., 1996a). AtT-20 cells are a neuroendocrine cell line that has been used extensively for studying the regulated secretory pathway (Moore et al., 1983). We also used an AtT-20 cell line stably transfected with $\alpha 1$-PDX cDNA that has been described previously (Benjannet et al., 1997). Special care was taken to ensure that cells were distributed in equal numbers in dishes that were to be used for group comparisons.

$V V$ recombinants and infections. Purified recombinant VVs containing the full-length coding regions of mouse pro-NGF, human pro-BDNF, and human pro-NT-3 (generously provided by Regeneron Pharmaceuticals) were constructed as described previously (Seidah et al., 1996a,b). VVs coding for $\alpha 1$-PDX were kindly provided by Dr. Gary Thomas (Vollum Institute, Portland, OR). Separate plates of cells were infected as described previously (Seidah et al., 1996a) with VV encoding proNGF, pro-BDNF, or pro-NT-3, generally at a multiplicity of infection (MOI) of 1 . We incubated the cells for $8-10 \mathrm{hr}$ in virus-free medium before metabolic labeling. In some experiments, plates were coinfected with pro-BDNF and either pro-NT-3 or pro-NGF, using an MOI of 0.5 for each. Under our experimental conditions, there was no evidence of cell death after exposure to VVs for the times indicated.

Construction of expression vectors and transfections. In some experiments, we transfected cells with DNA using the lipofectamine reagent (Life Technologies). cDNAs corresponding to the full-length coding regions of human pro-BDNF and human pro-NT-3 were subcloned into the pcDNA3 expression vector (Invitrogen, San Diego, CA). AtT-20 cells growing on poly-L-lysine-coated coverslips were transfected using lipofectamine with a constant amount of DNA ( $2 \mu \mathrm{g}$ DNA/2 ml medium) that was composed of expression vector alone (with no insert) together with $0.1,0.5,1$, or $2 \mu \mathrm{g}$ of pro-BDNF or pro-NT-3 plasmid DNA. After $5 \mathrm{hr}$ of incubation, the transfection medium was diluted 1:1 with DMEM/ $20 \%$ fetal calf serum, and after $2 \mathrm{~d}$, coverslips were processed for immunostaining (see below).

Metabolic labeling and immunoprecipitation. For pulse-chase experiments, we incubated infected cells with $1.5 \mathrm{ml}$ of Cys-Met-free DMEM containing $10 \%$ FCS and $0.5 \mathrm{mCi} / \mathrm{ml}\left[{ }^{35} \mathrm{~S}\right.$ ] Translabel (ICN Biochemicals, Costa Mesa, CA) (70\% methionine, 30\% cysteine) for $30 \mathrm{~min}$. Pro-BDNF contains eight methionines as compared with three in proNT-3, and mature BDNF contains three methionines as compared with none in mature NT-3. These differences, together with higher concentrations of methionine than cysteine in the Translabel, explain why, in
Figures showing the results of metabolic labeling experiments, proBDNF and mature BDNF label more heavily than pro-NT-3 and NT-3. For the chase periods, cells were washed, and the medium was replaced with an equal volume of DMEM containing 10\% FCS plus twofold excess concentrations of nonradioactive cysteine and methionine for the times indicated. In all experiments, conditioned media and cell lysates were brought to final volumes of $1.5 \mathrm{ml}, 750 \mu \mathrm{l}$ of which was subjected to immunoprecipitation. Samples immunoprecipitated with nonimmune rabbit IgG showed no bands corresponding to standards of neurotrophin precursors or products.

Immunoprecipitations were performed as described previously (Seidah et al., 1996a). For NT-3, we used an affinity-purified rabbit anti-NGF IgG that recognizes NT-3 (Murphy et al., 1993; Seidah et al., 1996a). BDNF immunoprecipitations were performed using an antibody kindly supplied by Amgen and characterized previously (Fawcett et al., 1997; Yan et al., 1997). Cell lysates and conditioned media were analyzed by electrophoresis on a 13-22\% SDS-PAGE. Gels were fixed in $40 \%$ methanol and 10\% acetic acid, treated with ENHANCE (Dupont NEN, Boston, MA), and washed in $10 \%$ glycerol, all for $1 \mathrm{hr}$. Dried gels were analyzed by a phosphorimaging device (Molecular Dynamics, Sunnyvale, $\mathrm{CA}$ ), and radioactivity in each band was quantitated using the ImageQuant program. Levels of radioactivity were within the linear range of the device. Statistical significance was determined using the Student's $t$ test on a minimum of triplicate experiments.

To monitor the effects of depolarization on neurotrophin release, we infected hippocampal neurons with recombinant viruses, metabolically labeled the cells for $30 \mathrm{~min}$, and washed and incubated the cells in medium containing excess nonradioactive methionine and cysteine for 4 hr. The cells were exposed to tissue culture medium supplemented with or without $\mathrm{KCl}(56 \mathrm{~mm})$ and $\mathrm{CaCl}_{2}(5.8 \mathrm{~mm})$ for $15 \mathrm{~min}$. Conditioned media and cell lysates were collected, immunoprecipitated, and fractionated by SDS-PAGE. Neurotrophin levels were estimated and compared by PhosphorImager analysis. In a previous control experiment (Mowla et al., 1999), we confirmed that $\mathrm{KCl}$ induces the release of endogenous secretogranin II in cultures of VV:NGF-infected hippocampal neurons to confirm that the regulated secretory pathway is fully functional in cells infected with VV constructs (Mowla et al., 1999).

Immunocytochemistry and confocal microscopy. We visualized VVinfected AtT-20 cells and primary cultures of hippocampal neurons as well as controls consisting of uninfected cells or cells infected with wild-type VVs. Cells were rinsed with PBS, fixed for $25 \mathrm{~min}$ in $4 \%$ paraformaldehyde $/ 15 \%$ picric acid in $0.1 \mathrm{M}$ phosphate buffer, $\mathrm{pH} 7.4$, and incubated in PBS containing 20\% horse serum for $30 \mathrm{~min}$ to reduce nonspecific binding. The cells were incubated with $1 \mu \mathrm{g} / \mathrm{ml}$ of affinitypurified anti-NT-3 (Chemicon, Temecula, CA) in PBS $/ 0.2 \%$ Triton X-100 overnight at $4^{\circ} \mathrm{C}$, washed three times with PBS $/ 0.05 \%$ Tween-20 (5 min each), and incubated for $1 \mathrm{hr}$ with CY3-conjugated goat anti-rabbit antibody (Jackson Laboratory, Bar Harbor, ME) diluted 1:2000 in PBS/ $0.05 \%$ Tween-20 containing $10 \%$ goat serum. Cells were washed three times in PBS and mounted in a Tris-buffered glycerol mounting medium (Sigma, St. Louis, MO). In control experiments, the anti-NT-3 antibody showed no detectable cross-reactivity by immunocytochemistry with either NGF or BDNF (data not shown).

Double-label immunocytochemistry was also performed on VVinfected AtT-20 cells to compare the distribution of NT-3 and NT-3/ BDNF with that of TGN38, a marker of the TGN (Luzio et al., 1990), and ACTH, which is packaged in secretory vesicles. Antibody to TGN38 raised in guinea pig (kindly provided by Drs. G. Banting and W. Garten) was used at a 1:50 dilution and visualized using an FITC-conjugated secondary antibody raised in goat (Jackson Laboratory) diluted 1:50 in PBS containing $10 \%$ goat serum. ACTH was localized with a monoclonal antibody (Cortex Biochem) at a dilution of 1:1000, visualized with a CY2-conjugated goat anti-mouse secondary antibody (Jackson Laboratory) diluted 1:1000 in PBS containing 10\% goat serum.

Cells were analyzed by confocal laser scanning microscopy using a Zeiss LSM 410 inverted confocal microscope and a $63 \times, 1.4$ NA objective. Cells were excited at $543 \mathrm{~nm}$ and imaged on a photomultiplier after passage through FT 590 and LP 590 filter sets. The confocal images represent one confocal level (a depth of $\sim 1 \mu \mathrm{m}$ ) that includes the cell nucleus along with as many cell processes as were possible to capture, the goal being to evaluate the distribution of secretory vesicles. No differences were evident in the distribution of NT-3 or NT-3/BDNF immunoreactivity when we scanned at various levels below or above the nucleus. 

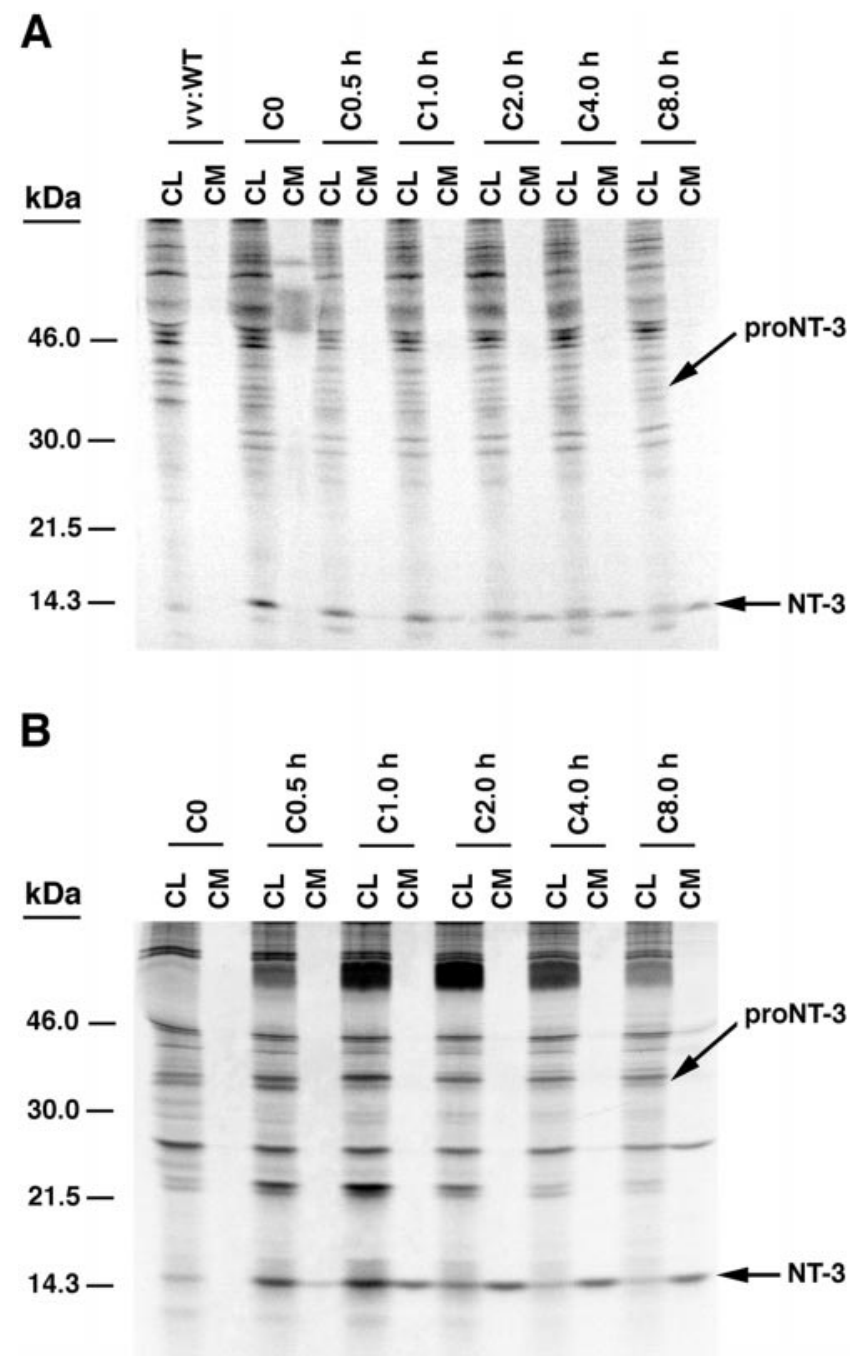

Figure 1. Pulse-chase metabolic labeling of pro-NT-3 in primary cultures of hippocampal neurons $(A)$ and AtT-20 cells $(B)$. Cells were infected with VV encoding the NT-3 precursor for $1 \mathrm{hr}$ and postincubated in fresh medium without virus for $8 \mathrm{hr}$. Cells were then exposed to medium containing $\left[{ }^{35} \mathrm{~S}\right] \mathrm{Cys}-$ Met for $30 \mathrm{~min}$ and chased for $0,0.5,1,2$, 4 , and $8 \mathrm{hr}$. Identical volumes $(750 \mu \mathrm{l})$ of cell lysates $(C L)$ and conditioned media $(C M)$ were incubated with antibodies to NGF, which immunoprecipitate NT-3, and electrophoresed on 13-22\% SDS gradient gels.

\section{RESULTS}

\section{NT-3 is released constitutively from hippocampal neurons and AtT-20 cells}

To determine the pathway by which NT-3 is processed and released, we did the following: (1) measured the retention or release of processed NT-3 from virally infected cells after pulsechase labeling; (2) determined whether agents that promote vesicle exocytosis promote the release of NT-3; and (3) used immunocytochemistry to visualize the intracellular localization of NT-3 in virally infected cells.

Figure 1 shows the results of $30 \mathrm{~min}$ pulse-chase studies performed over $8 \mathrm{hr}$ to monitor the processing of pro-NT-3 in primary cultures of hippocampal neurons (Fig. $1 A$ ) and in AtT-20 cells (Fig. $1 B$ ). In both cell types, pro-NT-3 $(33.5 \mathrm{kDa})$ is processed to mature NT-3 $(14.5 \mathrm{kDa})$. The precursor is detectable in cell lysates at the start of the chase period, and levels decrease thereafter; by $8 \mathrm{hr}$ of chase, the precursor is barely detectable.

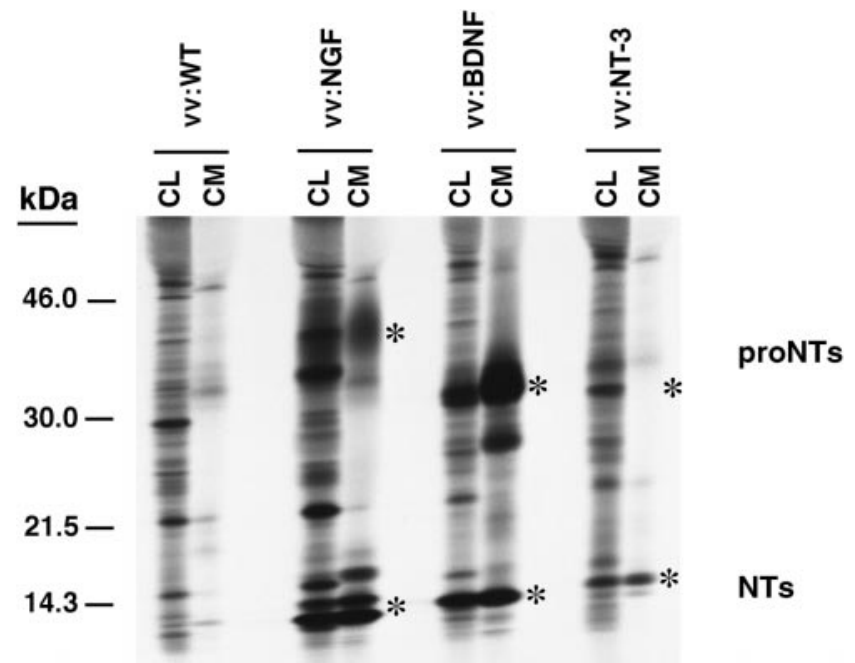

Figure 2. Differential processing of neurotrophin precursors in COS-1 cells, which contain only the constitutive secretory pathway. Cells were infected at an MOI of 1 with either wild-type $\mathrm{VV}(v v: W T)$ or $\mathrm{VV}$ encoding pro-NGF, pro-BDNF, or pro-NT-3. The cells were postincubated in the absence of virus for another $8 \mathrm{hr}$ and metabolically labeled for $3 \mathrm{hr}$. Identical volumes of cell lysates $(C L)$ and conditioned media $(C M)$ from $v v: W T$-, $v v: N G F$-, and $v v: N T$-3-infected cells were immunoprecipitated with an NGF antibody that recognizes both NGF and NT-3. $v v: B D N F$-infected cells were immunoprecipitated with a BDNF-specific antibody.

Intact pro-NT-3 is not detectable in conditioned medium at any time point in either cell type. Mature NT-3 is visible in cell lysates at the beginning of the chase period, but over time, levels in cell lysates decrease. Over the same time period, NT-3 levels in conditioned medium increase, and by $2 \mathrm{hr}$ they exceed those in cell lysates. Therefore, most newly processed NT-3 is rapidly released from both hippocampal neurons and AtT-20 cells.

We were surprised that levels of pro-NT-3 were so low in these cells and that processed NT-3 was evident immediately after the $30 \mathrm{~min}$ pulse period. In our previous studies, levels of pro-NGF and pro-BDNF were much higher at the beginning of the chase period, attributable in part to increased labeling efficiency (see Materials and Methods). Also, significant processing of pro-NGF and pro-BDNF was not evident until $30 \mathrm{~min}$ after the chase began. To test whether these differences were caused by pro-NT-3 being processed more efficiently in the constitutive pathway than either pro-NGF or pro-BDNF, we compared precursor processing in virally infected COS- 1 cells, a cell line that contains only the constitutive secretory pathway. Results show that abundant amounts of processed NGF and BDNF are detectable in cell lysates and conditioned medium at the end of the test period (Fig. 2 ). As well, significant levels of unprocessed pro-NGF and pro$\mathrm{BDNF}$ are detectable in cell lysates and in conditioned medium, which suggests that some precursor escapes proteolysis, perhaps by overwhelming the processing capacity of the cell (Mowla et al., 1999). In contrast, pro-NT-3 is detectable in cell lysates but not in conditioned medium, whereas processed NT-3 is evident in both. One explanation for these data is that pro-NT-3 is more efficiently processed within the constitutive secretory pathway than either pro-NGF or pro-BDNF.

We used pulse-chase labeling methods similar to those used in Figure 1 to determine whether the endoprotease furin, which is present in the constitutive pathway, is involved in pro-NT-3 processing in AtT-20 cells. For this experiment, we used AtT-20 


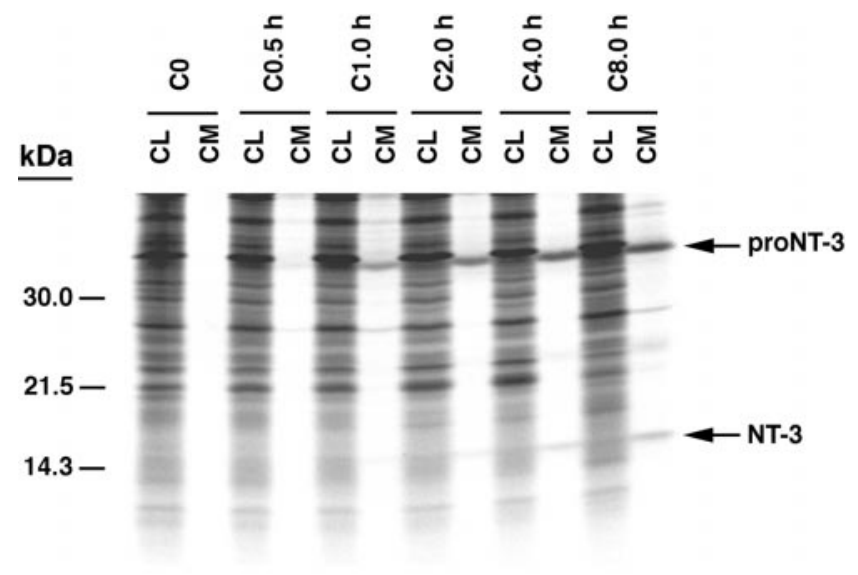

Figure 3. Inhibition of pro-NT-3 processing in AtT-20 cells expressing $\alpha 1$-PDX. AtT-20 cells stably expressing the furin inhibitor $\alpha 1$-PDX were infected for 30 min with VV encoding pro-NT-3. Cells were then incubated in virus-free medium for $8 \mathrm{hr}$, metabolically labeled for $30 \mathrm{~min}$, and chased for up to $8 \mathrm{hr}$. Cell lysates $(C L)$ and conditioned media $(C M)$ were immunoprecipitated and analyzed by SDS-PAGE.

cells that have been stably transfected with $\alpha 1$-PDX, an $\alpha 1$-antitrypsin structural variant that selectively inhibits furin-mediated cleavage of precursor proteins in the TGN (Anderson et al., 1993; Watanabe et al., 1995; Vollenweider et al., 1996; Benjannet et al., 1997). In cells expressing $\alpha 1$-PDX (Fig. 3), significant levels of pro-NT-3 are released into conditioned medium over the $8 \mathrm{hr}$ chase period, but levels of processed NT-3 are markedly reduced (compare Fig. 3 with Fig. 1B). Therefore, inhibition of furinmediated cleavage prevents the processing of pro-NT3 and the efficient generation of mature product.

The finding that $\alpha 1$-PDX prevents the processing of pro-NT-3 and induces its release into conditioned medium is identical to that obtained previously with pro-NGF (Mowla et al., 1999). In that study, we determined that inhibiting furin cleavage with $\alpha 1$-PDX caused the shunting of pro-NGF from the constitutive to the regulated secretory pathway (Mowla et al., 1999). We also observed that some pro-BDNF is constitutively released in the course of its processing within the regulated secretory pathway (Mowla et al., 1999). Together, these results suggest that inhibiting furin-mediated cleavage of pro-NT-3 may also direct the precursor from the constitutive to the regulated secretory pathway.

To test this idea, we monitored the effects of cAMP on NT-3 release from AtT-20 cells in the presence or absence of $\alpha 1$-PDX. We also used immunocytochemistry to analyze the distribution of NT-3 under both experimental conditions. Results show that cAMP stimulates the release of NT-3 from AtT-20 cells in the presence (Fig. 4, right panel) but not in the absence (left panel) of $\alpha 1-\mathrm{PDX}$. This result is consistent with immunocytochemical data (Fig. 5) showing that in the absence of $\alpha 1$-PDX (Fig. 5A), NT-3 immunoreactivity is distributed in the perinuclear cytoplasm and not in cell processes, an appearance identical to that previously reported for NGF (Mowla et al., 1999). However, in the presence of $\alpha 1$-PDX (Fig. $5 B$ ), punctate NT-3 immunoreactivity is evident throughout the cytoplasm and in the tips of cell processes, which is consistent with earlier results monitoring the distribution of BDNF in wild-type cells and NGF in $\alpha 1$-PDX-treated cells (Mowla et al., 1999). Thus NT-3, which is normally processed and released from the constitutive pathway, can be rerouted to the
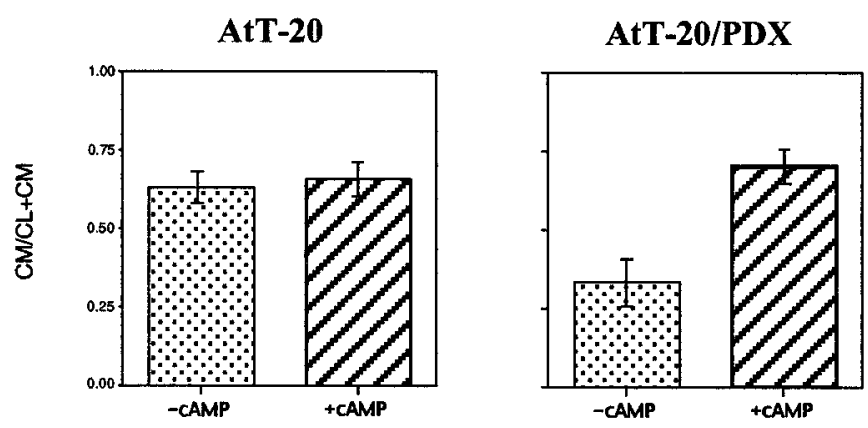

Figure 4. cAMP-induced release of NT-3 from AtT-20 cells expressing $\alpha 1$-PDX. Cells were infected with VV:pro-NT-3 for $1 \mathrm{hr}$, incubated in virus-free medium for $8 \mathrm{hr}$, metabolically labeled for $3 \mathrm{hr}$, chased for $3 \mathrm{hr}$, and treated for $3 \mathrm{hr}$ with medium with or without $5 \mathrm{mM} \mathrm{cAMP}$. CL and $\mathrm{CM}$ were immunoprecipitated and the amount of processed, mature NT-3 was analyzed by SDS-PAGE. Analysis was performed on a PhosphorImager, and values represent an average $( \pm$ SEM) of three independent experiments.

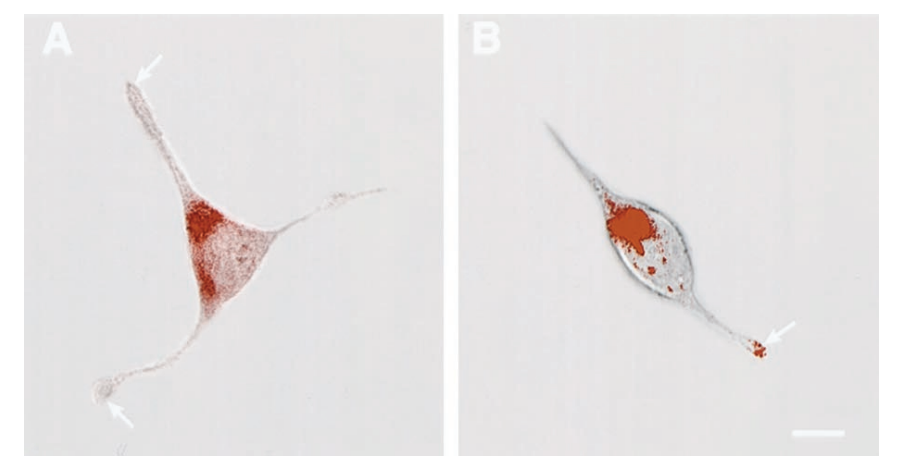

Figure 5. Confocal microscopy of AtT-20 $(A)$ and AtT-20/ $\alpha 1$-PDX cells $(B)$ infected with VV encoding pro-NT-3. Cells were infected for $1 \mathrm{hr}$ and postincubated in the absence of virus for another $8 \mathrm{hr}$. The cultures were fixed and treated with antibodies against NT-3 (Chemicon), followed by CY3-conjugated goat anti-rabbit IgG. Scale bar, $10 \mu \mathrm{m}$. Photomicrographs were obtained by overlaying confocal fluorescence images over transmitted light images. Scale bar, $10 \mu \mathrm{m}$.

regulated secretory pathway when furin-mediated cleavage within the TGN is inhibited.

In earlier studies, Heymach et al. (1996) and Moller et al. (1998) showed that NT-3 is packaged in dense-core vesicles of AtT-20 cells and PC12 cells and released in response to secretagogues or cell depolarization. To explain why their results differ from ours, we investigated whether elevating levels of pro-NT-3 expression could redirect NT-3 from the constitutive to the regulated secretory pathway, as has been shown previously for proNGF (Mowla et al., 1999). Initially, we determined that infecting AtT-20 cells with 5, 10, and 25 MOIs of VV encoding pro-NT-3 resulted in only a small amount of pro-NT-3 being redirected into the regulated secretory pathway, as determined by the ability of cAMP to induce NT-3 release (data not shown). Similar infection levels were extremely effective in rerouting NGF from the constitutive to regulated secretory pathway (Mowla et al., 1999). We suspect that the differences are attributable to pro-NT-3 being more efficiently processed than pro-NGF within the constitutive secretory pathway, as shown in Figure 2. To achieve higher intracellular concentrations of pro-NT-3, we opted for a lipofectamine transfection method similar to that used by Heymach et al. (1996) and Moller et al. (1998).

Lipofectamine transfection of pro-NT-3 DNA (0.1 $\mu \mathrm{g}$ with 1.9 

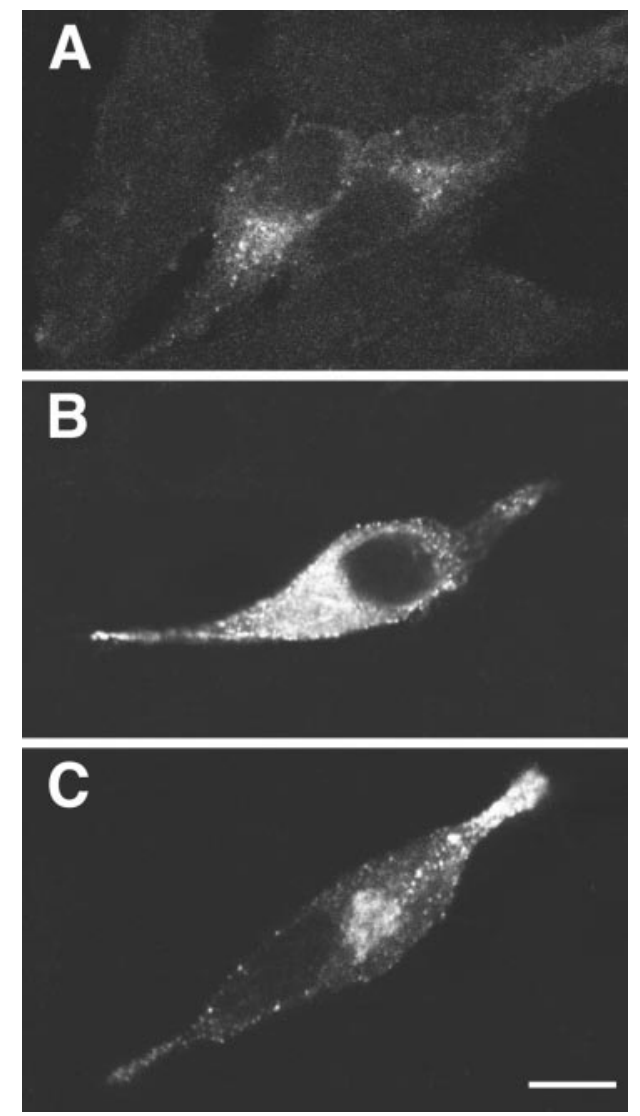

Figure 6. Overexpression of NT-3 results in rerouting from the constitutive to the regulated secretory pathway. AtT-20 cells were transfected with a construct encoding either pro-NT-3 $(A, B)$ or pro-BDNF $(C)$, and immunocytochemistry using NT-3 $(A, B)$ and BDNF $(C)$ antibodies was performed as described in Figure 5 . In $A$, cells were lipofectaminetransfected with $0.1 \mu \mathrm{g}$ of pro-NT-3 DNA (and $1.9 \mu \mathrm{g}$ vector DNA). In $B$, cells were transfected with $2 \mu \mathrm{g}$ pro-NT-3 DNA. In $C$, cells were transfected with $0.1 \mu \mathrm{g}$ of pro-BDNF (and $1.9 \mu \mathrm{g}$ vector DNA). Scale bar, $10 \mu \mathrm{m}$.

$\mu \mathrm{g}$ vector DNA/ $2 \mathrm{ml}$ of culture medium) resulted in NT-3 immunoreactivity in AtT-20 cells that is diffusely distributed in the perinuclear cytoplasm (Fig. 6A), as seen earlier (compare with Fig. $5 A$ ). However, when we transfected 0.5 or $1 \mu \mathrm{g}$ of pro-NT-3 DNA (with vector DNA to a total of $2 \mu \mathrm{g} / 2 \mathrm{ml}$ of culture medium), NT-3 immunoreactivity is evident in punctate structures that extend into cell processes, which is consistent with the appearance of secretory proteins processed in the regulated secretory pathway (Fig. $6 B$ ). For comparison, we show in Figure $6 C$ the punctate localization of BDNF immunoreactivity in cells exposed to only $0.1 \mu \mathrm{g}$ of pro-BDNF with $1.9 \mu \mathrm{g}$ of vector DNA/2 $\mathrm{ml}$ of culture medium. Pro-BDNF is processed within the regulated secretory pathway (Mowla et al., 1999). Thus, cells transfected with high concentrations of pro-NT-3 DNA process the protein in the regulated secretory pathway, which likely explains why our results with VV infection methods differ from those of Heymach et al. (1996) and Moller et al. (1998) using lipofectamine transfection.

\section{NT-3 is sorted to the regulated secretory pathway when coexpressed with pro-BDNF}

Because NT-3 is processed in the constitutive pathway and BDNF is processed in the regulated pathway (Mowla et al., 1999), we questioned what would happen if we coexpressed precursors to the two proteins within the same cell. Others have shown that neurotrophins readily heterodimerize (Radziejewski and Robinson, 1993; Arakawa et al., 1994; Jungbluth et al., 1994; Philo et al., 1994; Heymach and Shooter, 1995; Robinson et al., 1995; Treanor et al., 1995), but nothing is known about the mechanisms regulating the processing, sorting, and release of heterodimers within cells.

For these studies, we first analyzed the specificity of our antibodies, because previous studies have shown that antibodies to one neurotrophin can cross-react on Western blots with the other (Murphy et al., 1993). In these studies we infected AtT-20 cells for $1 \mathrm{hr}$ with $1 \mathrm{MOI}$ of VV coding for either pro-NT-3 or pro-BDNF, incubated the cells for $8 \mathrm{hr}$ without virus, metabolically labeled the cells for $3 \mathrm{hr}$, and immunopreciptated cell lysates and conditioned media with antibodies to NGF (for NT-3) or BDNF. In some experiments, we coinfected cells with 0.5 MOI of VV coding for pro-NT-3 and pro-BDNF to ensure that the total level of viral infection (1 MOI) was held constant.

Figure 7 (left side) shows that antibody to NGF immunoprecipitates NT-3 but not BDNF or pro-BDNF. Similarly, antibody to $\mathrm{BDNF}$ (Fig. 7, right side) immunoprecipitates $\mathrm{BDNF}$ and pro-BDNF but not NT-3. In contrast, in cells coinfected with VV coding for pro-NT-3 and pro-BDNF, antibody to NGF immunoprecipitates in conditioned medium NT-3 as well as a protein migrating in a position identical to that of pro-BDNF (Fig. 7, left side). We interpret this result to mean that NT-3 and pro-NT3 are associating with the BDNF precursor. In cell lysates as well as conditioned medium, the NGF antibody immunoprecipitates a doublet consisting of a higher molecular weight band (probably arising from precipitation of NT-3 alone and with BDNF) as well as a lower molecular weight band (BDNF) that precipitates because of association with NT-3. The right side of Figure 7 shows that antibodies to BDNF precipitate in cell lysates, and to a lesser extent in conditioned medium, a doublet consisting of a lower band (probably arising from precipitation of the BDNF alone or with NT-3) as well as an upper band (NT-3). Results identical to those shown in Figure 7 were obtained when the same experiments were performed in cultures of hippocampal neurons (data not shown).

In short, NT-3-specific antibodies precipitate BDNF, and BDNF-specific antibodies precipitate NT-3 only when the two neurotrophins are coexpressed within cells. We strongly suspect that these two independent but mutually consistent results arise from NT-3 and BDNF forming heterodimers intracellularly. Immunoprecipitation methods similar to ours were used previously by Jungbluth et al. (1994) and Heymach and Shooter (1995) to characterize neurotrophin heterodimers, including NT-3/BDNF. It should be noted that coinfection with wild-type and BDNFencoding VV and coinfection with VV:pro-NGF and VV:proBDNF did not result in coprecipitated neurotrophins (data not shown), probably because of the relative instability of $\mathrm{NGF}$ / BDNF heterodimers, as reported previously (Radziejewski and Robinson, 1993; Arakawa et al., 1994).

Evidence in support of the idea that coexpression of NT-3 with BDNF results in some NT-3 being shunted from the constitutive to the regulated secretory pathway is shown in Figure 8 . The bar graph (Fig. 8A) shows the amount of processed NT-3 in cell lysates as a function of the total amount of NT-3 present in cell lysates and conditioned media. Results indicate that more NT-3 is retained within cells when pro-NT-3 is coexpressed with proBDNF-encoding virus as compared with wild type. This result suggests that NT-3 and BDNF are noncovalently associated 


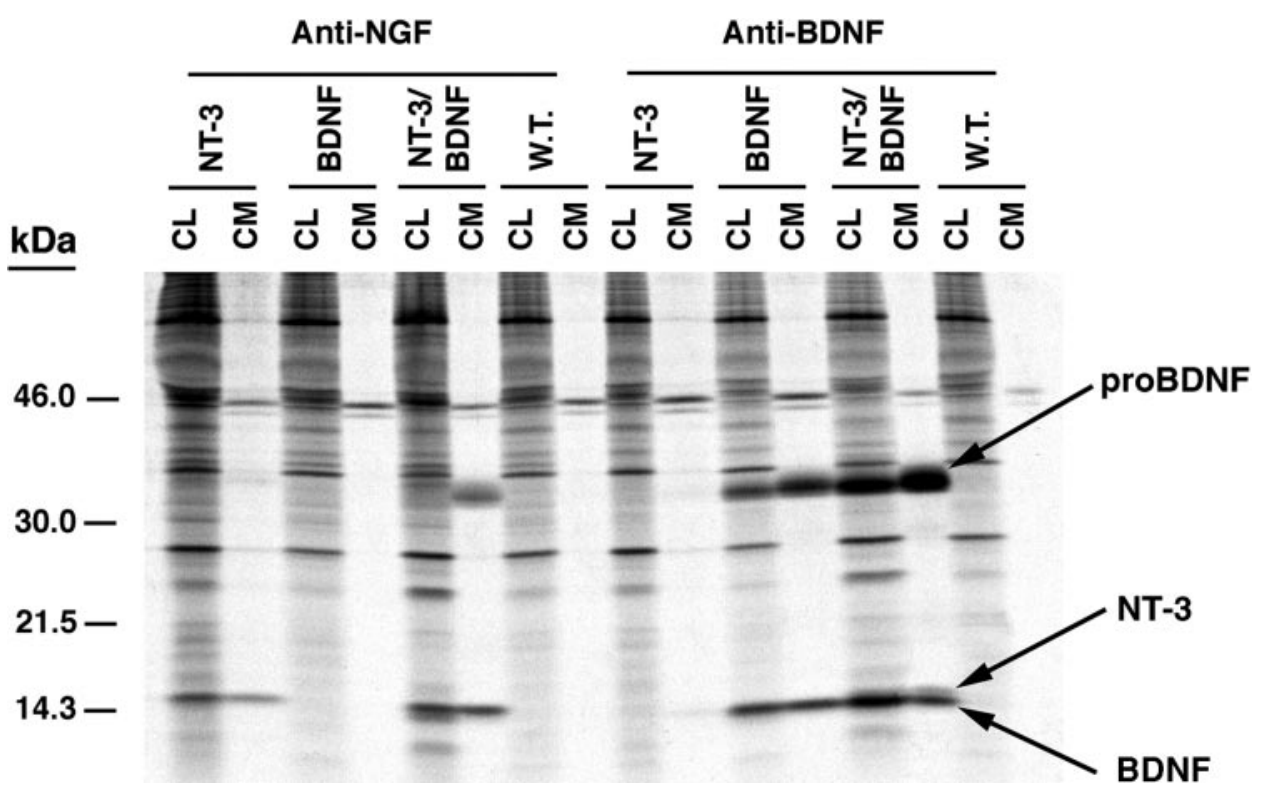

Figure 7. Immunoprecipitation of cell extracts and conditioned medium from cells infected with 1 MOI of wild type (W.T.) VV, V V:pro-NT-3, V V:pro-NGF, V V:proBDNF, alone, or coinfected with 0.5 MOI of pro-NT-3 and pro-BDNF. AtT-20 cells were infected for $1 \mathrm{hr}$ with the viruses indicated, postincubated for $8 \mathrm{hr}$, and metabolically labeled for $3 \mathrm{hr}$. Cell lysates and conditioned media were immunoprecipitated with either an anti-NGF antibody (left side) or a BDNF antibody (right side).

B

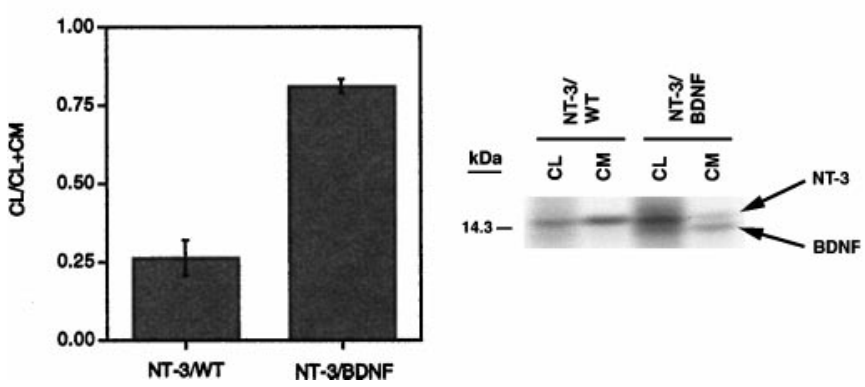

Figure 8. NT-3/BDNF is retained in hippocampal neurons. $A$, The methodology in Figure $1 A$ (involving a $4 \mathrm{hr}$ chase only) was repeated three times with cells infected with either VV:pro-NT-3/VV:WT or VV:pro-NT-3/VV:pro-BDNF. The NGF antibody was used for immunoprecipitations. Results were analyzed on a PhosphorImager and are an average $( \pm$ SEM $)$ of the ratio of mature NT-3 in cell lysates $(C L)$ over the total amount of NT-3 in CL + conditioned medium $(C M)$. $B$, A representative SDS gel from the experiments in $A$ showing the NT-3/BDNF heterodimer in the cell lysate and conditioned medium.

through heterodimerization and that association of the two leads to intracellular retention of NT-3, perhaps within dense-core vesicles. Examination of a typical SDS gel used in this analysis (Fig. $8 B$ ) shows that NT-3 and BDNF, which are coprecipitated by the NGF (NT-3-reactive) antibody, are evident within the cell lysate and conditioned medium, suggesting that coinfected cells synthesize and release the NT-3 and BDNF together. In companion experiments, coinfection with $\mathrm{VV}$ :pro-BDNF and $\mathrm{VV}$ : pro-NGF had no effect on NGF retention as compared with the wild-type coinfection control (data not shown).

The idea that NT-3 is diverted into the regulated secretory pathway is further confirmed by secretion data presented in Figure 9. When pro-NT-3 is coexpressed with pro-BDNF, processed NT-3 can be released from AtT-20 cells (Fig. 9A) in response to cAMP and from hippocampal neurons by $\mathrm{KCl}$ depolarization (Fig. 9B). Thus, release of NT-3 that is coexpressed (and presumably dimerized) with BDNF appears to be regulated by the same extracellular signals that regulate the release of homodimeric BDNF (Mowla et al., 1999). Cell lysates and con- ditioned media immunoprecipitated with NGF antibodies contained both NT-3 and BDNF, further indicating that the two neurotrophins are synthesized and released together in our culture system.

Finally, we used immunocytochemistry and confocal microscopy to compare the intracellular distributions of NT-3 and BDNF when they are singly expressed or coexpressed in hippocampal neurons. Figure 10 shows that in hippocampal neurons infected with 1 MOI of V V:pro-NT-3, NT-3 immunoreactivity is distributed in the perinuclear cytoplasm (Fig. 10A), as was seen in AtT-20 cells (Fig. 5). However, in cells coinfected with $0.5 \mathrm{MOI}$ of VV encoding pro-NT-3 and pro-BDNF, NT-3 immunoreactivity (Fig. 10C) is localized in punctate structures distributed throughout the cell cytoplasm and in the tips of cell processes, an appearance similar to that of BDNF immunoreactivity in cells infected with pro-BDNF alone (Fig. 10B). In control studies, coexpression of pro-NT-3 and pro-NGF did not change the distribution of NT-3, as assessed by immunocytochemistry (data not shown). Furthermore, coexpression of pro-BDNF and pro-NGF did not divert NGF from the constitutive to the regulated pathway as assessed by either immunoprecipitation or immunocytochemistry (data not shown).

Figure 11 compares the distribution in virally infected AtT-20 cells of NT-3 alone and NT-3 coexpressed with BDNF with that of endogenous TGN38, a Golgi marker, and endogenous ACTH, which is packaged within secretory granules of AtT-20 cells. In cells infected with VV:pro-NT-3 alone, immunoreactivity for NT-3 (Fig. 11 $A$ ) and TGN38 (Fig. 11B) colocalize in the perinuclear cytoplasm (Fig. 11C). In contrast, in cells coinfected with VV encoding pro-NT-3 and pro-BDNF, NT-3 immunoreactivity (Fig. 11D) is localized in the perinuclear cytoplasm as well as in punctate structures within the cytoplasm and tips of cell processes. In the same cells, ACTH immunoreactivity is distributed in punctate structures within cell processes (Fig. 11E). In a subpopulation of vesicles, NT-3 and ACTH immunoreactivity colocalize (Fig. 11F).

\section{DISCUSSION}

Data in this study show that NT-3 is processed and released from the constitutive secretory pathway of hippocampal neurons and 


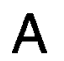

AtT-20

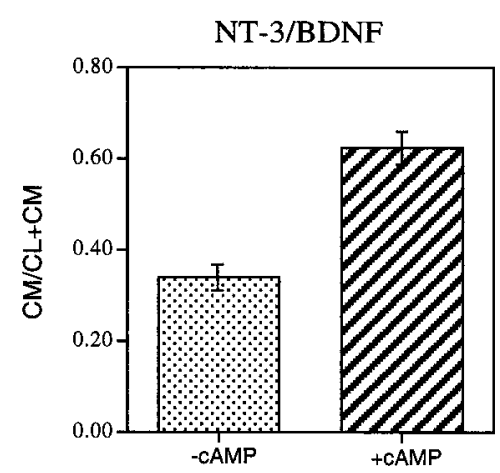

B

Hippocampal Neurons
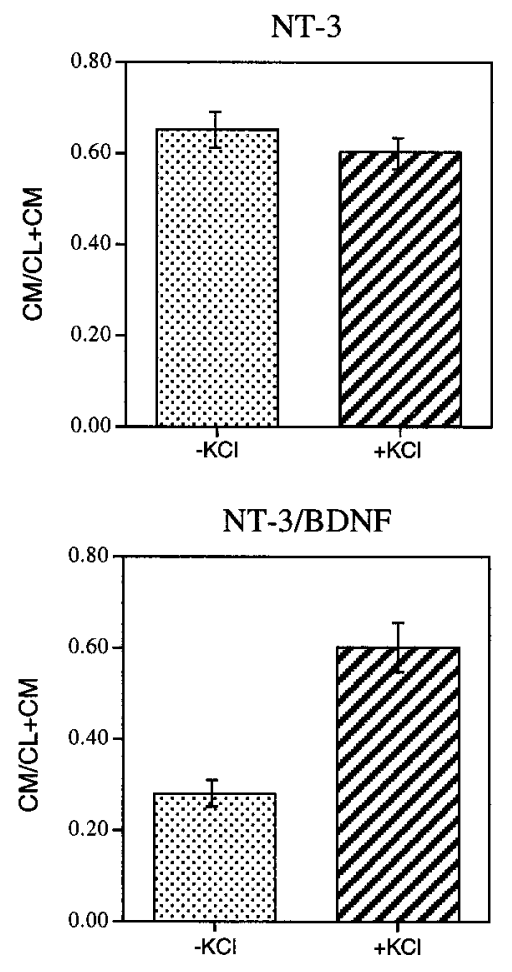

Figure 9. Secretagogue-induced release of NT-3/BDNF but not NT-3. $A$, AtT-20 cells coinfected with VV encoding pro-NT-3 and VV encoding pro-BDNF were processed using the methodology described in Figure 4. $B$, Hippocampal neurons from E18 mice were cultured for $7 \mathrm{~d}$ and infected for $1 \mathrm{hr}$ with either (1) VV encoding pro-NT-3 or (2) VV encoding pro-NT-3 and VV encoding pro-BDNF. After $8 \mathrm{hr}$ in medium without virus, the cells were labeled for $30 \mathrm{~min}$ with $\left[{ }^{35} \mathrm{~S}\right]$ Cys-Met, incubated in medium without radiolabel for $4 \mathrm{hr}$, and treated with medium with or without $\mathrm{KCl}$ and $\mathrm{CaCl}_{2}$ for $15 \mathrm{~min}$. Cell lysates and conditioned media were immunoprecipitated with the antibody to NGF and electrophoresed on an SDS gel. Results were analyzed on a PhosphorImager and are an average $( \pm$ SEM) of three independent experiments.

AtT-20 cells. Pulse-chase experiments reveal that the NT-3 precursor is rapidly cleaved in cells infected with VV encoding the NT-3 precursor (Fig. 1), with processed NT-3 being evident 30 min after cells are exposed to medium containing radiolabeled amino acids. Over the next $8 \mathrm{hr}$, most processed NT-3 is released into conditioned medium, a result similar to that reported previ-
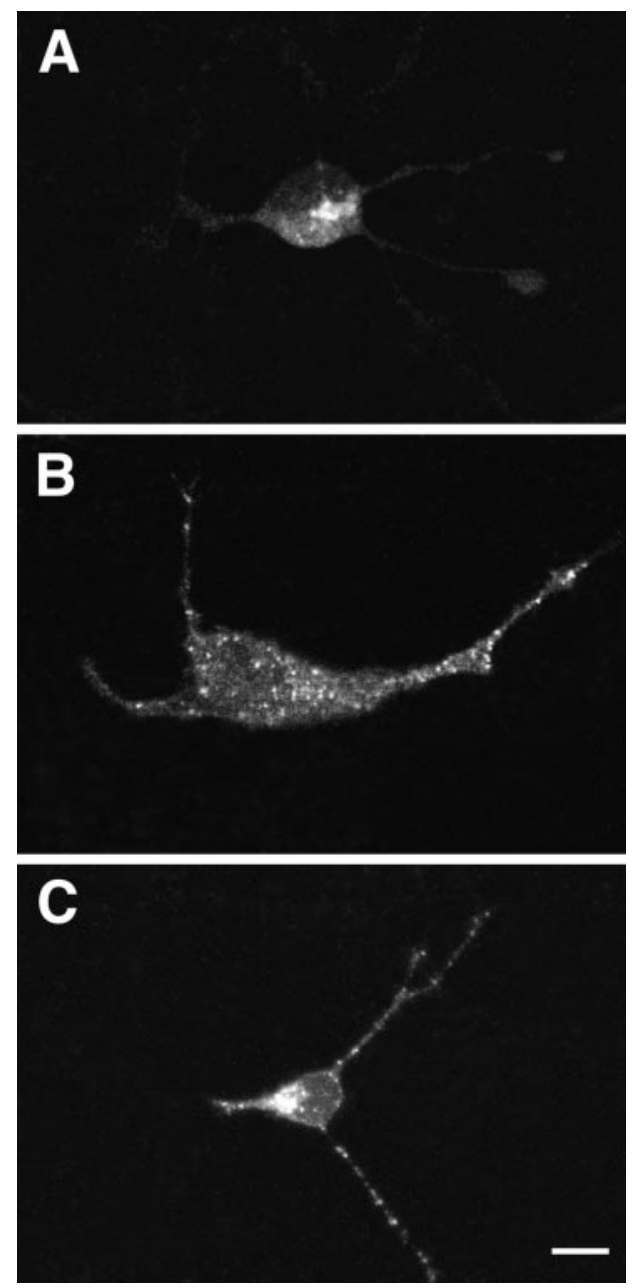

Figure 10. Confocal microscopy of hippocampal neurons infected with pro-NTs. Hippocampal neurons were infected with 1 MOI VV encoding either pro-NT-3 $(A)$ or pro-BDNF $(B)$; in $C$, the cells were coinfected with 0.5 MOI each of V V:pro-NT-3 and VV:pro-BDNF. Immunocytochemistry was performed with the NT-3 antibody in $A$ and $C$ and the BDNF antibody in $B$. Scale bar, $10 \mu \mathrm{m}$.

ously for NGF (Mowla et al., 1999). Immunocytochemical analysis shows that NT-3 is diffusely distributed within the perinuclear cytoplasm (Figs. 5, 10, 11), and colocalizes with TGN38, a marker of the trans-Golgi network (Figs. $11 A-C$ ). Secretagogues (Figs. 4, 9A) and KCl-induced depolarization (Fig. 9B) do not induce the release of radiolabeled NT-3 from virus-infected AtT-20 cells or hippocampal neurons, respectively. Thus, NT-3 release is constant and not dependent on extracellular cues, which is similar to the results we obtained for NGF (Mowla et al., 1999).

Pro-NGF, pro-BDNF, and pro-NT-3 were cleaved in COS-1 cells, which is a constitutively secreting cell line that does not have a regulated pathway. Most pro-BDNF and some pro-NGF (but not pro-NT-3) were released into conditioned medium (Fig. 2). This result could be attributable to pro-BDNF and to a lesser degree pro-NGF not being cleaved as effectively as pro-NT-3 by furin or furin-like enzymes within the TGN. The consensus cleavage site of pro-NT-3 (Arg-Arg-Lys-Arg $\downarrow$ Tyr) is ideally suited for furin-mediated processing, probably even more so than that of pro-NGF (Arg-Ser-Lys-Arg $\downarrow$ Ser) (Decroly et al., 1994). Basic residues at positions $-4,-2,-1$ are conducive to processing in the constitutive secretory pathway (Watanabe et al., 1992). How- 

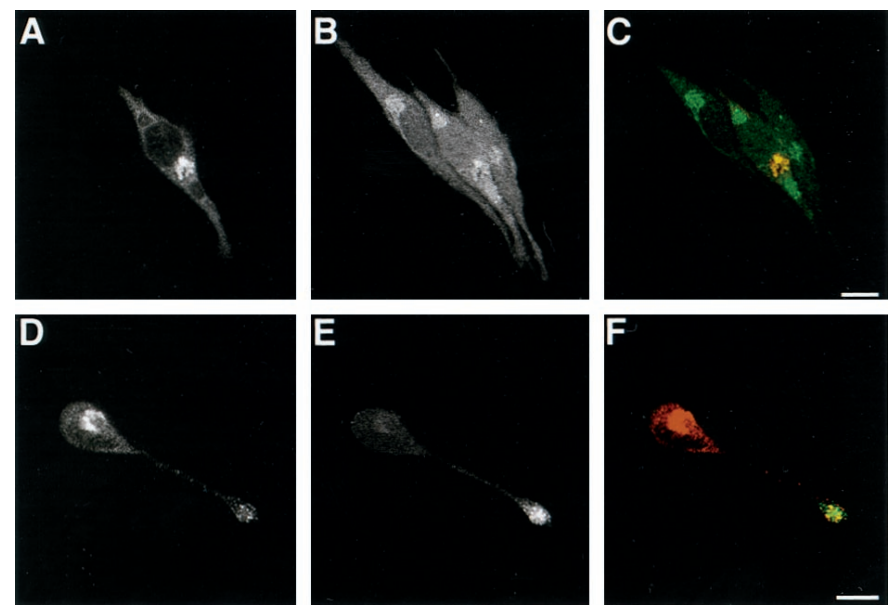

Figure 11. Double-label immunocytochemistry comparing the distribution in infected AtT-20 cells of NT-3 and NT-3/BDNF with that of endogenous TGN38 and ACTH. NT-3 immunoreactivity $(A)$ colocalizes with TGN38 $(B)$ in the perinuclear region as seen in $C$ (NT-3 in red and TGN38 in green). NT-3 immunoreactivity in cells coinfected with proNT-3 and pro-BDNF $(D)$ colocalizes with ACTH $(E)$ primarily in the tip of the cellular process as seen in $F$ (NT-3 in red and ACTH in green). Scale bar, $10 \mu \mathrm{m}$.

ever, the presence of an additional Arg residue at position -3 in pro-NT-3 may enhance even more the ability of furin to cleave the protein at this site.

Although it has yet to be shown directly with neurotrophin precursors, several lines of evidence suggest that sensitivity to furin-mediated cleavage within the TGN is an important factor in determining whether a protein is sorted to the constitutive or regulated secretory pathway (Brechler et al., 1996). In this study, blocking furin activity with $\alpha 1$-PDX inhibited pro-NT-3 processing in the constitutive pathway and resulted in the constitutive release of unprocessed pro-NT-3 (Fig. 3). In addition, $\alpha 1-P D X$ treatment caused a shift in the appearance of NT-3 immunoreactivity from diffuse and perinuclear to punctate and distributed throughout the cell cytoplasm, including in the tips of cell processes (Fig. 5). Also, processed NT-3 was released by cAMP treatment (Fig. 4), which is characteristic of proteins within the regulated secretory pathway. Insertion of furin-sensitive cleavage sites into precursors that are normally processed in the regulated secretory pathway favors release through the constitutive secretory pathway (Oda et al., 1991; Yanagita et al., 1992), which is further evidence of the importance of furin sensitivity in the sorting decision (Jung and Scheller, 1991; Brechler et al., 1996; Mowla et al., 1999).

Increasing the MOI of vaccinia virus also shifted pro-NGF from the constitutive to the regulated secretory pathway (Edwards et al., 1988; Mowla et al., 1999), probably by saturating the ability of furin to cleave pro-NGF as a substrate. However, increasing MOI had little effect on the subcellular localization of NT-3 (data not shown), probably because pro-NT-3 is especially well cleaved in the TGN by furin. In contrast, lipofectamine transfection methods (Fig. 6) resulted in NT-3 immunoreactivity becoming localized within punctate structures throughout the cytoplasm and in the tips of cell processes. Lipofectamine transfection may yield higher intracellular concentrations of neurotrophin precursors in the comparatively small number of cells that are transformed $(<10 \%)$ when compared with vaccinia virus infection ( $>90 \%$ cells infected). These differences in intracellular levels of the protein can be inferred by comparing NT-3 immunoreactivity in lipofectamine-transfected cells (Fig. 6B) with that of vaccinia virus-infected cells (Fig. 11A). The differences probably explain why Heymach et al. (1996) and Moller et al. (1998) detected NT-3 within the regulated secretory pathway of AtT-20 and PC12 cells. Similarly, increasing expression levels altered the intracellular distribution of $\beta 2$-microglobulin in pancreatic $\beta$ cells of transgenic mice (Allison et al., 1991).

Exogenously applied NT-3 is as effective as BDNF in potentiating synaptic efficacy in hippocampal CA1 neurons, which suggests that NT-3, like BDNF, may normally access the synapse through its activity-dependent release from presynaptic neurons (Kang and Schuman, 1995). However, removing endogenous NT-3 has no effect on long-term potentiation (LTP) in mouse hippocampal CA1 neurons (Chen et al., 1999; Ma et al., 1999). In contrast, blocking endogenous BDNF reduces LTP (Korte et al., 1995). Thus, exogenously applied NT-3 may mimic the effects of BDNF through mechanisms that are unrelated to the way NT-3 normally accesses the synapse (Chen et al., 1999).

Neurotrophin heterodimers have not yet been detected in vivo, even with antibodies that recognize them specifically (Kolbeck et al., 1999). However, neurotrophins can form stable heterodimers either when renatured together or coexpressed in cells (Radziejewski and Robinson, 1993; Arakawa et al., 1994; Jungbluth et al., 1994; Philo et al., 1994; Heymach and Shooter, 1995; Robinson et al., 1995; Treanor et al., 1995). Thus, cells that coexpress neurotrophins such as hippocampal neurons (Maisonpierre et al., 1990; Schecterson and Bothwell, 1992) could produce heterodimeric forms of these proteins. The NT-3/BDNF heterodimer is especially stable (Arakawa et al., 1994), which has allowed its crystal structure to be resolved (Robinson et al., 1995).

In our experiments, coexpressing pro-NT-3 and pro-BDNF resulted in the retention of NT-3 within vesicle-like structures that were distributed throughout the cytoplasm and within cellular processes of both AtT-20 cells and hippocampal neurons, a distribution that was identical to that of BDNF (Mowla et al., 1999). NT-3 was also released together with BDNF in response to secretagogues or depolarization. These data together with our coimmunoprecipitation studies strongly suggest that in our experimental system, NT-3 and BDNF heterodimerize, as shown previously by others (Philo et al., 1994; Heymach and Shooter, 1995). However, confirming that idea will require isolating the heterodimers to purity and characterizing them chemically, which we have not done.

As yet, we do not know how NT-3/BDNF heterodimers form. Protein dimerization normally occurs between monomers of unprocessed precursors in the endoplasmic reticulum (Danielsen, 1990; Zhu et al., 1996), which would yield pro-NT-3/pro-BDNF heterodimers. However, heterodimers could also exist between NT-3, which is efficiently processed in the TGN, and pro-BDNF, which is processed in immature secretory granules. Indeed, in our coimmunoprecipitation experiments, we detect within conditioned medium pro-BDNF along with mature NT-3 and BDNF. Further processing of the NT-3/pro-BDNF heterodimer likely occurs in immature secretory granules to yield heterodimers of mature forms of NT-3 and BDNF.

Others have noted previously that heterodimerization can alter the intracellular trafficking of proteins. For example, the common $\alpha$-subunit of lutropin, follitropin, and chorionic gonadotropin is constitutively secreted when produced alone; however, heterodimerization with the appropriate $\beta$-subunit causes the heterodimer to be sorted and released by the regulated secretory 
pathway (Blomquist and Baenziger, 1992; Bielinska et al., 1994). Apparently, a single chain of a protein destined for the regulated secretory pathway contains sufficient information to reroute the entire heterodimeric complex.

The finding that pro-NT-3 can be released from either the constitutive or regulated secretory pathways suggests that NT-3 could have multiple functions. The release of homodimeric NT-3 from the constitutive secretory pathway would allow NT-3 to be constantly available as a differentiation and survival-promoting factor for neurons, which appears to be its role during development (for review, see Chalazonitis, 1996). In contrast, when NT-3 heterodimerizes with BDNF, as may occur when both are highly expressed in adult hippocampus (Maisonpierre et al., 1990), NT-3 is sorted to the regulated secretory pathway, where the NT-3/ $\mathrm{BDNF}$ heterodimer is packaged within vesicles that are released in response to activity. Under these conditions, NT-3 acting at TrkC receptors or NT-3/BDNF heterodimers acting in concert at TrkC and TrkB receptors (Philo et al., 1994) could regulate synaptic transmission and plasticity. Thus, understanding how NT-3 is processed in specific populations of neurons at different times of development could reveal much about its physiological functions.

\section{REFERENCES}

Acheson A, Barker PA, Alderson RF, Miller FD, Murphy RA (1991) Detection of brain-derived neurotrophic factor-like activity in fibroblasts and Schwann cells: inhibition by antibodies to NGF. Neuron $7: 265-275$.

Allison J, Malcolm L, Culvenor J, Batholomeusz RK, Holmberg K, Miller JFAP (1991) Overexpression of $\beta 2$-microglobulin in transgenic mouse islet $\beta$ cells results in defective insulin secretion. Proc Natl Acad Sci USA 88:2070-2074.

Altar CA, DiStefano PS (1998) Neurotrophin trafficking by anterograde transport. Trends Neurosci 21:433-437.

Anderson ED, Thomas L, Hayflick JS, Thomas G (1993) Inhibition of HIV-1 gp160-dependent membrane fusion by a furin-directed $\alpha 1$ antitrypsin variant. J Biol Chem 268:24887-24891.

Arakawa T, Haniu M, Narhi LO, Miller JA, Talvenheimo J, Philo JS, Chute HT, Matheson C, Carnahan J, Louis JC, Yan Q, Welcher AA, Rosenfeld R (1994) Formation of heterodimers from three neurotrophins, nerve growth factor, neurotrophin-3, and brain-derived neurotrophic factor. J Biol Chem 269:27833-27839.

Banker GA, Cowan WM (1977) Rat hippocampal neurons in dispersed cell culture. Brain Res 126:397-442.

Benjannet S, Savaria D, Laslop A, Munzer JC, Chretien M, Marcinkiewicz M, Seidah NG (1997) $\alpha 1$-antitrypsin Portland inhibits processing of precursors mediated by pro-protein convertases primarily within the constitutive secretory pathway. J Biol Chem 272:26210-26218.

Bielinska M, Rzymkiewicz D, Boime I (1994) Human luteinizing hormone and chorionic gonadotropin are targeted to a regulated secretory pathway in $\mathrm{GH}_{3}$ cells. Mol Endocrinol 8:919-928.

Blomquist JF, Baenziger JU (1992) Differential sorting of lutropin and the free $\alpha$-subunit in cultured bovine pituitary cells. J Biol Chem 267:20798-20803.

Brechler V, Chu WN, Baxter JD, Thibault G, Reudelhuber TL (1996) A protease processing site is essential for prorenin sorting to the regulated secretory pathway. J Biol Chem 271:20636-20640.

Brewer GJ, Torricelli JR, Evege EK, Price PJ (1993) Optimized survival of hippocampal neurons in B27-supplemented Neurobasal, a new serum-free medium combination. J Neurosci Res 35:567-576.

Chalazonitis A (1996) Neurotrophin-3 as an essential signal for the developing nervous system. Mol Neurobiol 12:39-53.

Chen G, Kolbeck R, Barde YA, Bonhoeffer T, Kossel A (1999) Relative contribution of endogenous neurotrophins in hippocampal long-term potentiation. J Neurosci 19:7983-7990.

Danielsen EM (1990) Perturbation of intestinal microvillar enzyme biosynthesis by amino acid analogs. Evidence that dimerization is required for the transport of aminopeptidase $\mathrm{N}$ out of the endoplasmic reticulum J Biol Chem 265:14566-14571.

Decroly E, Vandenbranden M, Ruysschaert JM, Cogniaux J, Jacob GS,
Howard SC, Marshall G, Kompelli A, Basak A, Jean F (1994) The convertases furin and $\mathrm{PC} 1$ can both cleave the human immunodeficiency virus (HIV)-1 envelope glycoprotein gp160 into gp120 (HIV-1 SU) and gp41 (HIV-I TM). J Biol Chem 269:12240-12247.

Edwards RH, Selby MJ, Mobley WC, Weinrich SL, Hruby DE, Rutter WJ (1988) Processing and secretion of nerve growth factor: expression in mammalian cells with a vaccinia virus vector. Mol Cell Biol 8:2456-2464.

Farhadi HF, Mowla SJ, Petrecca K, Morris SJ, Seidah NG, Murphy RA (1998) Constitutively secreted neurotrophin-3 can be directed to the regulated secretory pathway by dimerization with BDNF. Soc Neurosci Abstr 28:318.3.

Fawcett JP, Aloyz R, McLean JH, Pareek S, Miller FD, McPherson PS, Murphy RA (1997) Detection of brain-derived neurotrophic factor in a vesicular fraction of brain synaptosomes. J Biol Chem 272:8837-8840.

Fawcett JP, Alonso-Vanegas MA, Morris SJ, Miller FD, Sadikot AF, Murphy RA (2000) Evidence that brain-derived neurotrophic factor from presynaptic nerve terminals regulates the phenotype of calbindincontaining neurons in the lateral septum. J Neurosci 20:274-282.

Goodman LJ, Valverde J, Lim F, Geschwind MD, Federoff HJ, Geller AI, Hefti F (1996) Regulated release and polarized localization of brain-derived neurotrophic factor in hippocampal neurons. Mol Cell Neurosci 7:222-238.

Heymach JV, Shooter EM (1995) The biosynthesis of neurotrophin heterodimers by transfected mammalian cells. J Biol Chem 270:12297-12304.

Heymach JV, Kruttgen A, Suter U, Shooter EM (1996) The regulated secretion and vectorial targeting of neurotrophins in neuroendocrine and epithelial cells. J Biol Chem 271:25430-25437.

Jung LJ, Scheller RH (1991) Peptide processing and targeting in the neuronal secretory pathway. Science 251:1330-1335.

Jungbluth S, Bailey K, Barde YA (1994) Purification and characterisation of a brain-derived neurotrophic factor/neurotrophin-3 (BDNF/ NT-3) heterodimer. Eur J Biochem 221:677-685.

Kang H, Schuman EM (1995) Long-lasting neurotrophin-induced enhancement of synaptic transmission in the adult hippocampus. Science 267:1658-1662.

Kafitz KW, Rose CR, Thoenen H, Konnerth A (1999) Neurotrophinevoked rapid excitation through TrkB receptors. Nature 401:918-921.

Kolbeck R, Bartke I, Eberle W, Barde YA (1999) Brain-derived neurotrophic factor levels in the nervous system of wild-type and neurotrophin gene mutant mice. J Neurochem 72:1930-1938.

Korte M, Carroll P, Wolff E, Brem G, Thoenen H, Bonhoeffer T (1995) Hippocampal long-term potentiation is impaired in mice lacking brainderived neurotrophic factor. Proc Natl Acad Sci USA 92:8856-8860.

Luzio JP, Brake B, Banting G, Howell KE, Bragetta P, Stanley KK (1990) Identification, sequencing, and expression of an internal membrane protein of the trans-Golgi network (TGN38). Biochem J 270:97-102.

Ma L, Reis G, Parada LF, Schuman EM (1999) Neuronal NT-3 is not required for synaptic transmission or long-term potentiation in area CA1 of the adult rat hippocampus. Learn Mem 6:267-275.

Maisonpierre PC, Belluscio L, Friedman B, Alderson RF, Wiegand SJ, Furth ME, Lindsay RM, Yancopoulos GD (1990) NT-3, BDNF, and NGF in the developing rat nervous system: parallel as well as reciprocal patterns of expression. Neuron 5:501-509.

McAllister AK, Katz LC, Lo DC (1999) Neurotrophins and synaptic plasticity. Annu Rev Neurosci 22:295-318.

Michael GJ, Averill S, Nitkunan A, Rattray M, Bennett DLH, Yan Q, Priestly JV (1997) Nerve growth factor treatment increases brainderived neurotrophic factor selectively in TrkA-expressing dorsal root ganglion cells and in their central terminations within the spinal cord. J Neurosci 17:8476-8490.

Moller JC, Kruttgen A, Heymach JV, Ghori N, Shooter EM (1998) Subcellular localization of epitope-tagged neurotrophins in neuroendocrine cells. J Neurosci Res 51:463-472.

Moore HP, Walker MD, Lee F, Kelly RB (1983) Expressing a human proinsulin cDNA in a mouse ACTH-secreting cell. Intracellular storage, proteolytic processing, and secretion on stimulation. Cell 35:531-538.

Mowla SJ, Pareek S, Farhadi HF, Petrecca K, Fawcett JP, Seidah NG, Morris SJ, Sossin WS, Murphy RA (1999) Differential sorting of nerve growth factor and brain-derived neurotrophic factor in hippocampal neurons. J Neurosci 19:2069-2080. 
Murphy RA, Acheson A, Hodges R, Haskins J, Richards C, Reklow E, Chlumecky V, Barker PA, Alderson RF, Lindsay RM (1993) Immunological relationships of NGF, BDNF, and NT-3: recognition and functional inhibition by antibodies to NGF. J Neurosci 13:2853-2862.

Oda K, Ikeda M, Tsuji E, Sohda M, Takami N, Misumi Y, Ikehara Y (1991) Sequence requirements for proteolytic cleavage of precursors with paired basic amino acids. Biophys Biochem Res Commun 179:1181-1186.

Philo J, Talvenheimo J, Wen J, Rosenfeld R, Welcher A, Arakawa T (1994) Interactions of neurotrophin-3 (NT-3), brain-derived neurotrophic factor (BDNF), and the NT-3·BDNF heterodimer with the extracellular domains of the TrkB and TrkC receptors. J Biol Chem 269:27840-27846.

Radziejewski C, Robinson RC (1993) Heterodimers of the neurotrophic factors: formation, isolation, and differential stability. Biochemistry 32:13350-13356.

Robinson RC, Radziejewski C, Stuart DI, Yvonne Jones E (1995) Structure of the brain-derived neurotrophic factor/neurotrophin 3 heterodimer. Biochemistry 34:4139-4146.

Seidah NG, Benjannet S, Pareek S, Chretien M, Murphy RA (1996a) Cellular processing of the neurotrophin precursors of NT3 and BDNF by the mammalian proprotein convertases. FEBS Lett 379:247-250.

Seidah NG, Benjannet S, Pareek S, Savaria D, Hamelin J, Goulet B, Laliberte J, Lazure C, Chretien M, Murphy RA (1996b) Cellular processing of the nerve growth factor precursor by the mammalian pro-protein convertases. Biochem J 314:951-960.

Seidah NG, Day R, Marcinkiewicz M, Chretien M (1998) Precursor convertases: an evolutionary ancient, cell-specific, combinatorial mechanism yielding diverse bioactive peptides and proteins. Ann NY Acad Sci 839:9-24.

Schecterson LC, Bothwell M (1992) Novel roles for neurotrophins are suggested by BDNF and NT-3 mRNA expression in developing neurons. Neuron 9:449-463.

Treanor JJ, Schmelzer C, Knusel B, Winslow JW, Shelton DL, Hefti F, Nikolics K, Burton LE (1995) Heterodimeric neurotrophins induce phosphorylation of Trk receptors and promote neuronal differentiation in PC12 cells. J Biol Chem 270:23104-23110.

Ventimiglia R, Mather PE, Jones BE, Lindsay RM (1995) The neurotrophins BDNF, NT-3, and NT-4/5 promote survival and morphological and biochemical differentiation of striatal neurons in vitro. Eur J Neurosci 7:213-222.

Vollenweider F, Benjannet S, Decroly E, Savaria D, Lazur C, Thomas G, Chretien M, Seidah NG (1996) Comparative cellular processing of the human immunodeficiency virus (HIV-1) envelope glycoprotein gp160 by the mammalian subtilisin/kexin-like convertases. Biochem $\mathrm{J}$ 314:521-532.

Watanabe T, Nakagawa T, Ikemizu J, Nagahama M, Murakami K, Nakayama K (1992) Sequence requirements for precursor cleavage within the constitutive secretory pathway. J Biol Chem 267:8270-8274.

Watanabe M, Hirano A, Stenglein S, Nelson J, Thomas G, Wong TC (1995) Engineered serine protease inhibitor prevents furin-catalyzed activation of the fusion glycoprotein and production of infectious measles virus. J Virol 69:3206-3210.

Yan Q, Rosenfeld RD, Metheson CR, Hawkins N, Lopez OT, Bennett L, Welcher AA (1997) Expression of brain-derived neurotrophic factor protein in the adult rat central nervous system. Neuroscience 78:431-448.

Yanagita M, Nakayama K, Takeuchi T (1992) Processing of mutated proinsulin with tetrabasic cleavage sites to bioactive insulin in the non-endocrine cell line, COS-7. FEBS Lett 311:55-59.

Yuen EC, Howe CL, Li Y, Holtzman DM, Mobley WC (1996) Nerve growth factor and the neurotrophic factor hypothesis. Brain Dev 18:362-368.

Zhou A, Webb G, Zhu X, Steiner DF (1999) Proteolytic processing in the secretory pathway. J Biol Chem 274:20745-20748.

Zhu G, Jaskiewicz E, Bassi R, Darling DS, Young Jr WW (1996) Dimerization of lactase-phlorizin hydrolase occurs in the endoplasmic reticulum, involves the putative membrane spanning domain and is required for an efficient transport of the enzyme to the cell surface. Eur J Cell Biol 3:198-208. 